DOI: https://doi.org/10.33989/2075-146x.2021.27.247044

УДК 81'243:378.147

\title{
SOFIA HORBUNOVA
}

ORCID: 0000-0001-8023-5851

\section{YURI DZEKUN}

ORCID: 0000-0001-6342-7245

\section{VALENTYNA ISCHENKO}

ORCID: 0000-0002-4812-0859

Higher Educational Establishment "Poltava University of Economics and Trade"

\section{DISCUSSION AS AN APPROACH TO DEVELOPING COMMUNICATIVE COMPETENCIES}

The article considers discussion as an active approach to teaching foreign languages and the development of communicative competencies, given the use of a communicative approach to learning. The phenomenon of discussion, stages of its organization, presence of discussion tasks in educational materials are analyzed. The possibility of using discussion in foreign language classes as an interactive form of learning is considered. It was found that the main task of the discussion is to involve different points of view in the active discussion of problems in a foreign language, which, in turn, stimulates the cognitive interest of students. The main role of the teacher in ensuring the effectiveness of the discussion in the classroom is determined. The results of research on the efficacy of discussion show that the correct use of this method will increase the effectiveness of foreign language classes. Wide application of the method of discussion in solving problem situations promotes the development of logical, independent and critical thinking of students, allows them to acquire important personal and social activities skills to express and defend their point of view and at the same time listen to other people's opinions.

Key words: communicative approach, teaching methods, discussion, linguistic personality, secondary linguistic personality, communicative competence, interactive teaching methods

Statement of the problem in general and an indication of its connection with important scientific or practical tasks. Higher education institutions have always had the goal of releasing into the big world a person who would be able to solve any task set before them, despite the complexity or uncertainty of the conditions. The need for creative, active, gifted, intellectually and spiritually developed citizens determines the orientation of the educational process on the formation and development of personality, which is also capable of self-improvement, self-education and selfdevelopment, which uses acquired knowledge to creatively solve life problems and seeks to realize themselves in their professional field.

Given the process of globalization, it becomes necessary for graduates of higher education institutions to be aware not only of their professional field, but also to know at least one foreign language. English is by far the most widely studied second language in the world. It is studied by $97 \%$ of European high school students (EF EPI EF English ...). In turn, knowledge of a foreign language is not only knowledge of vocabulary and grammar, but also the ability to use the acquired knowledge with the greatest benefit and efficiency, to communicate freely in the international space. Today, experts in any field cannot afford to miss out on global innovation due to language barriers, and researchers are not alone in needing free access to new ideas. This includes the formation of a certain set of different competencies necessary for his formation as an individual and a member of society.

The relevance of the work is determined by the need to form students' knowledge of a foreign language, skills of its use and the development of independence and creative thinking. Students' communicative competence is directly related to their successes and achievements in later professional life, so its development should be given close attention. And today, English primarily assists to establish connections between people. The analysis of teaching materials and practical classes, during which discussions were used as a method of teaching, provides a scientific novelty of this article.

Formulation of the purpose and tasks of the article. The purpose of the work is to substantiate the introduction of discussions in the process of teaching English based on their undeniable potential as interactive teaching methods and analysis of the main advantages and disadvantages of their use. Based on the purpose, the task was to explore the main 
types of such interactive forms of learning as discussion, whether they are presented in teaching materials and in what quantities, and to justify the use of them in English language classes as an approach to developing "linguistic personality" and communicative competences. The main research methods for this work were the method of observation and descriptive method and the method of analysis.

The object of the study was practical classes in English, which used the methods of discussion, and the subject, in turn, the features of the use of interactive teaching methods, in particular, discussions. The material was theoretical works of Ukrainian and foreign researchers and analyzed textbooks which are used in classes and classes in the disciplines "Foreign language" and "Foreign language for specific purposes", as well as questionnaires of students.

Analysis of the most important publications in which the solution of the researched problem is initiated and on which the authors rely. The concept of "linguistic personality" in modern science is rightly considered interdisciplinary, since it reflects the philosophical, psychological, social, cultural and purely linguistic aspects. This concept was first introduced in the 1930s by V. Vinogradov. Based on the definition given in the "Short Explanatory Dictionary" edited by S. Yermolenko, under the linguistic personality scholars understand "the combination in the person of the speaker of his language competence, the desire for creative expression, free, automatic implementation of diverse language activities. Linguistic personality consciously refers to his language practice, bearing the imprint of the social, territorial environment, traditions of education in the national culture" (Срмоленко, 2001, с. 93).

Within the general concept of "linguistic personality" there is a more specific - "secondary linguistic personality" (N. Galskova, Y. Karaulov, M. Kolpakova, O. Leontovich, I. Khaleeva (Халеева, 1995), and it is focused on the formation of such a personality through the process of learning foreign languages. Interpretation of the secondary language personality is based on involvement through a non-native language not only in the secondary language system of foreign linguistic culture, but also in the conceptual picture, within which the formation of national character and mentality of the native speaker (Халеева, 1995, с. 277). Thus, the secondary linguistic personality is a set of human traits that involves mastering the verbal-semantic code of the language being studied, i.e. the "linguistic picture of the world" of speakers of this language, as well as a conceptual picture of the world .In English language classes it is appropriate to use different teaching methods to achieve different goals and objectives. The development of communicative competence requires the use of interactive teaching methods that involve active interaction between teacher and students.

Statement of the main material with a full justification of the obtained scientific results. According to the EF English Proficiency Index report (EF EPI EF English...), for 2020 Ukraine is in 44th place among European countries with the indicator "Average level of English proficiency". A group of university students, as a microcosm, can confirm this statistic. For example, according to the results of the Placement test, which was held among 1 st year students, for 31 people in a group: 8 have B1 level, 18 - A2 level, 4 - A1 level, 1 student - did not study English at school, which, evidently, gives an average result with level A2, but in practice creates gaps and difficulties in the learning process.

The development of a student's communicative competence is an important component since, according to the definition above, a language personality is characterized not only by knowledge but also by skills. Theoretical stock of information, which is not supported by practical skills of application of this information, is an inefficient resource. Therefore, the teacher's task is to organize the educational process in such a way that the theoretical and practical knowledge students learn to use as effectively as possible. In other words, communicative competence is the ability and real readiness of a student to communicate freely in accordance with the goals, areas and situations of real communication, readiness for adequate language interaction and mutual understanding.

One of the effective approaches among interactive forms of learning is discussion (Пометун, 2004, с. 54). Discussion - 1) a method of learning that involves the organization of joint language activities in order to find an effective solution to a problem; 2) one of the methods of resolving controversial issues (Пометун, 2004, c. 141). Scientist Ch. Kupisevych notes: "The essence of the discussion is the exchange of views on a particular topic between teachers and students or only between students" (Куписевич, 1986, с. 142). Effective discussion is characterized by a variety of opinions, the desire to find the most acceptable solution to the didactic problem and the active participation of interlocutors. Discussions are sometimes used by teachers who want to reduce their speaking time in order to engage more students in the language they are learning. However, we must not forget that the teacher must also take an active part in the discussion, support and monitor it. Despite the fact that the teacher must demonstrate to students a high style of argumentation of their position, teach students to accurately express their views and be tolerant of their wording, respectfully amend their arguments, and, if necessary, eliminate the dominance of one participant over another.

Discussions in English language classes (for example, in the discipline of "Foreign language" or "Foreign language for specific purposes") are used by teachers to achieve various learning goals. The most important are the following:

- assist students to build their own utterances in English. Discussing the topic encourages students to develop their listening and speaking skills, increases their ability to think in English, encourages them to evolve critical thinking skills and abilities to express personal opinion;

- to promote the involvement of students in further public discussions. In order for effective learning to take place, students cannot depend solely on the teacher and must take responsibility for their own independent learning. Using discussions is one way to do this, as it allows students to express their own thoughts and ideas; 
- to assist students to understand the importance of communication skills (developing of communication skills). Discussions provide the teacher with the means to find out which speech skills students are already fluent in and which skills still need further development (Топтигіна, 2001).

The sample of analysed material included the following textbooks and studying materials: "Outcomes. PreIntermediate" (National Geographic Learning), "Navigate. Elementary" (Oxford), "Keynote. Upper-Intermediate" (National Geographic Learning), "New English File. Pre-Intermediate" (Oxford), "New English File. UpperIntermediate" (Oxford), "Market Leader. Pre-Intermediate" (Longman), "Market Leader. Upper-Intermediate" (Longman).

Examples of tasks presented in them:

- SPEAKING. 1 Work in groups. Look at the photo and discuss the questions.. What do you think the people are learning? Where do you think it is? Why do you think they are learning this? Do you think it's a good idea? What adult education programmes are there where you live? Have you studied or learned a skill outside of school or university? What? ("Outcomes. Pre-Intermediate") (Dellar, Walkley, 2018).

- Work in small groups. Read what three people say about shopping. Which is most true for you? Give

more information.

"I don't like shopping. It's boring./I love shopping and I go all the time./I only shop when I need something." ("Navigate. Elementary") (Hughes, Wood, 2015).

- STARTING UP: Statement: The best way to have a good idea is to have a lot of ideas.(Dr. Linus Pauling (1901-1994), American chemist) Which of the following statements do you agree with? Which do you disagree with? Why? 1 There are no new ideas. 2 Most of the best ideas are discovered by accident. 3 Research and development is the key to great business ideas. 4 There is nothing wrong with copying and improving the ideas of others. 5 The best way to kill an idea is to take it to a meeting. What should companies do to encourage new ideas? ("Market Leader. Pre-Intermediate") (Cotton, Falvey, Kent, 2005).

After analyzing the textbooks and teaching materials that are used during training, we can conclude that discussion, as a method of developing communicative competence, does not receive proper disclosure, and requires additional preparatory actions from the teacher. Often, textbooks use proverbs, statements of famous people, etc., offering to express their opinion from the position of "agree/disagree", at higher levels may be asked to argue their opinion with additional examples.

However, the potential for discussion is not limited to these exercises. Students can be offered to answer contradictory questions, which cannot be answered simply "yes" or "no", for example: "Would you rather know how you die or when you die?", "Have you ever had a problem with bullying?", "What is on your bucket list?". Another idea is to invite students to participate in Online Discussion, using classroom social-media pages, or online forums such as Blackboard, encouraging classroom discussion as homework or part of a classroom activity. Teachers are able to introduce lessons during the school day, but assign a classroom discussion to students as a homework assignment. Additionally we can mention Round-Table Format discussion. According to Yale University's Center for Teaching and Learning choosing a round-table classroom format most closely resembles the type of setting that students will encounter when meeting with colleagues, or business associates, once they enter their careers. Using this method, teachers can also sit among students, which allows all members of the discussion to speak in a more comfortable, equal setting (12 POWERFUL DISCUSSION...).

An interesting approach in modern conditions, when the online learning format prevails over the offline one, can be Color-Coded Conversations. Whether teaching English remotely or in person, Ashley Bible's method makes it a point to provide ample opportunity for shy students to thrive. One of her go-to silent discussion strategies is a ColorCoded Conversation using a shared document. Teacher needs to set up a shared document (Google documents, Online boards etc.) with a table that will fit all of your students plus the topics you want them to discuss. The idea is to instruct students to choose a unique colour, font, or combo for their name. This specific color / font will follow them throughout the discussion (12 POWERFUL DISCUSSION...).

It is also possible to use a discussion approach integrating it with other activities, such as project work in groups or individually. Students prepare a presentation or report on a specific topic, adhering to a certain position, and the remaining group members can express both their consent and disagreement, discussing the results of the research and analysis of the topic.

One should not lose sight of spontaneous topics for discussions that arise by themselves, in connection with changes in modern society, politics, culture, etc. Today's events of cultural and social significance, such as concerts and elections, summits and film awards, natural disasters, etc., can be interesting for students, so such topics are often discussed in class. The teacher can use the interest of students to encourage them to discuss. In such a situation there is a natural process of communication. This type of discussion allows students to formulate and express independent thinking and their own thoughts. When discussing an interesting topic, students no longer need constant encouragement from the teacher. 
In practical classes in groups (2 groups of 1st year students of specialties "Hotel and restaurant business", "Expertise and customs"), to start the discussion, students were offered the following topics, based on their relevance: "Creative thinking. Is it necessary?", "Key to success. If at first you don't succeed?", "The environmental impact of the hospitality industry", "Is honesty the best policy?", "Modern tendencies in cinema. Is Oscar now better than before?", "Perks of being online (advantages and disadvantages of distant learning)".

Classes on these topics were conducted in accordance with the rules of discussions (Куписевич, 1986, с. 55): a topic was chosen, a plan and an approximate list of issues for discussion were elaborated. During the discussion, students expressed their thoughts, shared their experiences and emotionally responded to the comments of their classmates. The topic related to cinema aroused great interest among students, everyone tried to share their own opinions about the contenders and winners in various categories, and defended their position on the impressions of the films. The proposed topic on distance education aroused interest among students, as they had the opportunity to compare distance learning and face-to-face training (the learning process due to a pandemic was organized via the distance learning platform Moodle).

After the classes, students were offered questionnaires with questions:

1. Do you find the discussions useful and necessary as an obligatory element in the course of the lesson? (Answer options: "Yes", "No", "I find it difficult to answer")

2. Do you feel uncomfortable expressing your opinion in front of an audience? (Answer options: "Yes", "No", "I find it difficult to answer")

3. Have you changed your mind after discussing the topic in class? (Answer options: "Yes", "No", "I find it difficult to answer")

4. Do you consider the topics covered in the class to be relevant? (Answer options: "Yes", "No", "I find it difficult to answer")

5. What topics are interesting, prioritised and important for you? (Open-ended question)

6. What would you like to add? (Open-ended question)

The survey showed that, in general, students are aware of the importance and usefulness of discussions, support the idea of using such approaches during their studies and feel the need to discuss contemporary issues related to the modern life of our society. Of the two groups of students (29 people, 31 people, respectively), 44 people answered the first question in the affirmative, 13 in the negative, and 3 people chose the option "Difficult to answer". The answer to the second question was "yes" for 12 people, the answer "no" for 48 people. Third question: "yes" - 12 people, "no" 48 people. The students answered the fourth question as follows: agreed - 46 people, answered negatively - 9 people, abstained - 5 people. Of the topics proposed by students, the most common ones were: modern international politics, modern technologies and inventions, scientific achievements, environmental problems, art (including contemporary art), problems of tolerance, problems of modern education (online education).

After analyzing the results, we can conclude that students, for the most part (more than $70 \%$ of respondents), are interested in this form of work in the classroom, noting the benefits and effectiveness of discussing the topic from different angles. Students note that after discussions they do not change their point of view on problematic topics, but they have more respect for the views and beliefs of their peers.

From the standpoint of an English language teacher, the analysis of the classes allowed the teacher to identify the strengths and weaknesses of each, and the presence of "gaps" in the vocabulary of some students. It revealed the range of interests in the group and provided an opportunity to organize further training based on this information. The disadvantages of this form of work include the problems of deviation from the topic mentioned by students, sometimes too harsh comments on the views of others. Problems in conducting discussion sessions in groups include the lack of the necessary friendly atmosphere of trust and the need to create rules for discussions. However, the experience of group discussions can be considered successful.

Discussion is an effective method of teaching, but for greater efficiency it can be combined with other activities in the classroom and in independent work. Preparation of presentations and projects with their further discussion, reading and listening to texts, messages that contain information that would be an interesting topic for discussion. Short questionand-answer sessions on reading materials can provide teachers with tools that allow them to test students' comprehension of texts as well as increase students' motivation to complete further tasks.

Results of the research and prospects for further development of this thematic area. Most educational institutions and individual educators are convinced that in today's world, English language proficiency is a significant advantage. However, not everyone knows how to obtain it. We note that the discussion is highly effective for consolidating information and educational material, creative understanding of the study, the formation of value orientation, as well as the formation of communicative competence of students studying English. Wide application of the method of discussion in solving problem situations promotes the development of logical, independent and critical thinking of students, allows them to acquire important personal and social activities skills to express and defend their point of view and at the same time listen to other people's opinions. Clearly, discussion is not the ultimate means of developing students' communicative competence. To use it effectively, the teacher needs to develop their own strategies for developing and sustaining discussions in English language classes that take into account students' abilities, taking into account their 
strengths and weaknesses. Also, care must be taken not to abuse discussions as the only possible means of learning. It is necessary to use all available means and methods available to the teacher, so that the development of language personality takes place evenly and comprehensively.

\section{Список використаних джерел}

Єрмоленко, С. Я. (2001). Украӥнська мова: Короткий тлумачний словник лінгвістичних термінів. Київ: Либідь. Куписевич, Ч. (1986). Основы общей дидактики. Москва: Высшая школа.

Мартинець, А. М. (2003). Нові педагогічні технології: інтерактивне навчання. Відкритий урок, 7-8, 28-31.

Пометун, О. (2004). Сучасний урок. Інтерактивні технологї̈ навчання: наук.-метод. посіб. Київ.

Тарнопольский, О. Б. (2006). Методика навчання іншомовної мовленнєвої діяльності у вищому мовному закладі освіти: навч. посіб. Київ: Фірма "НІКОС".

Топтигіна, Н. М. (2001). Психолінгвістичні та комунікативні аспекти навчаль-ної дискусії у процесі вивчення іноземної мови. Теоретичні питання освіти та виховання, 15, 92-96.

Халеева, И. И. (1995). Вторичная языковая личность как реципиент инофонного текста. В кн. Язык-система. Язык-текст. Язык-способность (с. 277-278). Москва: Ин-т русского языка РАН.

Ягупов, В. В. (2003). Педагогіка: [навч. посіб.] Київ: Либідь.

12 POWERFUL DISCUSSION STRATEGIES TO ENGAGE STUDENTS: $\quad$ веб-сайт. Retrieved from https://www.readingandwritinghaven.com/12-powerful-discussion-strategies-to-engage-students/ (дата звернення 20.06.2021)

Brown, H. D. (2000). Teaching by principles: an interactive approach to language pedagogy. New York: Longman.

Cotton, D., Falvey, D., Kent, S. (2005). Market Leader. Pre-Intermediate Business English. Longman Ltd.

Cotton, D., Falvey, D., Kent, S. (2008). Market Leader. Upper-Intermediate Business English. Longman Ltd.

Dellar, H., Walkley, A. (2018). Outcomes. Pre-Intermediate. Student's book. National Geographic Learning.

EF EPI EF English Proficiency Index. Рейтинг 100 стран и регионов по уровню владения английским языком. Retrieved from https://www.ef.com/assetscdn/WIBIwq6RdJvcD9bc8RMd/legacy/_/ /media/centralefcom/epi/downloads/fullreports/v10/ef-epi-2020-russian.pdf (дата звернення 20.06.2021)

Hughes, J., Wood, K. (2015). Navigate. Elementary. Course book with video. Oxford University Press.

Stephenson, H., Lansford, L., \& Dummet, P. (2017). Keynote. Upper-Intermediate. Student's book. National Geographic Learning.

\section{References}

12 POWERFUL DISCUSSION STRATEGIES TO ENGAGE STUDENTS: веб-сайт. Retrieved from https://www.readingandwritinghaven.com/12-powerful-discussion-strategies-to-engage-students/.

Brown, H. D. (2000). Teaching by principles: an interactive approach to language pedagogy. New York: Longman.

Cotton, D., Falvey, D., Kent, S. (2005). Market Leader. Pre-Intermediate Business English. Longman Ltd.

Cotton, D., Falvey, D., Kent, S. (2008). Market Leader. Upper-Intermediate Business English. Longman Ltd.

Dellar, H., Walkley, A. (2018). Outcomes. Pre-Intermediate. Student's book. National Geographic Learning.

EF EPI EF English Proficiency Index. Рейтинг 100 стран и регионов по уровню владения английским языком. Retrieved from https://www.ef.com/assetscdn/WIBIwq6RdJvcD9bc8RMd/legacy/_/ /media/centralefcom/epi/downloads/fullreports/v10/ef-epi-2020-russian.pdf.

Hughes, J., Wood, K. (2015). Navigate. Elementary. Course book with video. Oxford University Press.

Khaleeva, I. I. (1995). Vtorichnaia iazykovaia lichnost kak retcipient inofonnogo teksta [Secondary linguistic personality as a recipient of a foreign text]. In Iazyk-sistema. Iazyk-tekst. Iazyk-sposobnost [Language-system. Language-text. Languageability] (pp. 277-278). Moskva: In-t russkogo iazyka RAN [in Russian].

Kupisevich, Ch. (1986). Osnovy obshchei didaktiki [Fundamentals of General Didactics]. Moskva: Vysshaia shkola [in Russian].

Martynets, A. M. (2003). Novi pedahohichni tekhnolohii: interaktyvne navchannia [New pedagogical technologies: interactive learning]. Vidkrytyi urok [Open lesson], 7-8, 28-31 [in Ukrainian].

Pometun, O. (2004). Suchasnyi urok. Interaktyvni tekhnolohii navchannia [A modern lesson. Interactive learning technologies]: nauk.-metod. posib. Kyiv [in Ukrainian].

Stephenson, H., Lansford, L., \& Dummet, P. (2017). Keynote. Upper-Intermediate. Student's book. National Geographic Learning.

Tarnopolskyi, O. B. (2006). Metodyka navchannia inshomovnoi movlennievoi diialnosti u vyshchomu movnomu zakladi osvity [Methods of teaching foreign language speech activity in a higher language educational institution]: navch. posib. Kyiv: Firma "NIKOS" [in Ukrainian].

Toptyhina, N. M. (2001). Psykholinhvistychni ta komunikatyvni aspekty navchal-noi dyskusii u protsesi vyvchennia inozemnoi movy [Psycholinguistic and communicative aspects of educational discussion in the process of learning a foreign language]. Teoretychni pytannia osvity ta vykhovannia [Theoretical issues of education and upbringing], 15, 92-96 [in Ukrainian].

Yahupov, V. V. (2003). Pedahohika [Pedagogy]: [navch. posib.] Kyiv: Lybid [in Ukrainian].

Yermolenko, S. Ya. (2001). Ukrainska mova [Ukrainian language]: Korotkyi tlumachnyi slovnyk linhvistychnykh terminiv. Kyiv: Lybid [in Ukrainian]. 


\section{ГОРБУНЬОВА С., ДЗЕКУН Ю., ІЩЕНКО В.}

Вищий навчальний заклад Укоопспілки «Полтавський університет економіки і торгівлі», Україна

\section{ДИСКУСІЯ ЯК ПІДХІД ДО РОЗВИТКУ КОМУНІКАТИВНИХ КОМПЕТЕНЦІЙ}

У статті розглянуто дискусію як активний метод навчання іноземних мов та розвитку комунікативних компетентностей, з огляду на використання комунікативного підходу до навчання. Проаналізовано феномен дискусії, етапи іiі організації, наявність дискутивних завдань у навчальних матеріалах. Розглядається можливість використання на заняттях з іноземної мови дискусії, як інтерактивної форми навчання. 3'ясовано, що головним завданням дискусії залучення різних точок зору в активне обговорення проблем іноземною мовою, що, в свою чергу, стимулює пізнавальний інтерес студентів. Визначено основну роль викладача у забезпеченні ефективності дискусії на занятті.

Загалом, результати проведеного дослідження доводять, що правильне використання методу дискусії дозволить підняти ефективність занять з іноземної мови. Широке застосування методу дискусії при вирішенні проблемних ситуацій сприяє розвитку логічного, самостійного і критичного мислення студентів, дозволяє їм набути важливих для особистої та громадської діяльності вмінь висловлювати та відстоювати свою точку зору та у цей же час прислуховуватися до чужої думки.

Ключові слова: комунікативний підхід, методи навчання, дискусія, мовна особистість, вторинна мовна особистість, комунікативна компетентність, інтерактивні методи навчання

Стаття надійшла до редакції 10.05.2021 p. 